\title{
Tolerance of Corn (Zea mays L.) to Early and Late Glyphosate Applications
}

\author{
Kris J. Mahoney ${ }^{*}$, Robert E. Nurse2, Wesley J. Everman³, Christy L. Sprague4, \\ Peter H. Sikkema ${ }^{1}$ \\ ${ }^{1}$ University of Guelph, Ridgetown Campus, Ridgetown, Canada \\ ${ }^{2}$ Agriculture and Agri-Food Canada, Harrow, Canada \\ ${ }^{3}$ North Carolina State University, Raleigh, USA \\ ${ }^{4}$ Michigan State University, East Lansing, USA \\ Email: ${ }^{*}$ kmahoney@uoguelph.ca
}

Received 3 June 2014; revised 17 July 2014; accepted 9 August 2014

Copyright (C) 2014 by authors and Scientific Research Publishing Inc.

This work is licensed under the Creative Commons Attribution International License (CC BY).

http://creativecommons.org/licenses/by/4.0/

c) (i) Open Access

\section{Abstract}

Fifteen field experiments were conducted from 2009 to 2012 in Ontario, Canada and Michigan, USA to determine the tolerance of corn (Zea mays L.) to early (spike or 1- to 2-leaf stage) or late (8or 10-leaf stage) applications of 900, 1800, 3600, or $7200 \mathrm{~g} \cdot \mathrm{ae}^{-h^{-1}} \mathrm{of}^{-1}$ glyphosate. Postemergence applications were evaluated for corn injury, cob length and deformity, crop moisture at harvest, and yield in the absence of weed competition. In the early application experiment, no visible injury was detected with applications of up to $3600 \mathrm{~g} \cdot \mathrm{ae} \cdot \mathrm{ha}^{-1}$; however, $1.4 \%$ injury was observed 4 weeks after treatment (WAT) when $7200 \mathrm{~g} \cdot \mathrm{ae}^{-h^{-1}}$ was applied to 1- to 2-leaf stage corn. Yet by harvest, the observed injury was transient as yields were similar to the untreated control regardless of glyphosate dose or timing. In the late application experiment, visible injury tended to increase with glyphosate dose. In addition, for corn treated with $7200 \mathrm{~g} \cdot \mathbf{a e} \cdot \mathbf{h a}^{-1}$ at the 10 -leaf stage, injury increased over time as $6 \%, 11 \%$, and $12 \%$ injury was observed 1,2 , and 4 WAT, respectively. Similar to the visible injury of vegetative tissue, cob deformity and reductions in yield tended to increase with glyphosate dose, but this response varied and the data were pooled into two environment groups. For example, in one environment group, corn treated with 7200 g.ae $\cdot \mathrm{ha}^{-1}$ at the 8 - and 10 -leaf stage had a $9.5 \%$ and $14.6 \%$ reduction in yield, respectively. Whereas in another environment group, corn yields were similar to the untreated control regardless of glyphosate dose or timing. This research demonstrated that commercially available corn hybrids have tolerance to glyphosate at doses greater than what has been previously published or could reasonably be expected during spray overlaps in a field.

${ }^{*}$ Corresponding author. 


\section{Keywords}

\section{Dose, Injury, Cob Deformity, Yield}

\section{Introduction}

Researchers first began efforts to develop glyphosate-resistant corn (Zea mays L.) in the 1980s [1]. To date, three strategies have been used to achieve glyphosate resistance in corn: 1) expression of an insensitive target enzyme (5-enolpyruvylshikimate-3-phosphate synthase, EPSPS), 2) expression of a foreign, insensitive EPSPS, and 3) expression of glyphosate detoxification genes [2] [3] with varying levels of success. For example, reference [4] reported that corn expressing an insensitive EPSPS (aroA ${ }_{1398}$ ) from bacterial strain ATX1398 could tolerate $3408 \mathrm{~g} \cdot \mathrm{ae} \cdot \mathrm{ha}^{-1}$ of glyphosate without injury. Reference [5] found that corn expressing a glyphosate detoxification gene (glyphosate $N$-acetyltransferase, gat) could tolerate $6840 \mathrm{~g} \cdot \mathrm{ae} \cdot \mathrm{ha}^{-1}$ of glyphosate without injury. However, most commercially available corn hybrids contain the NK603 transgenic event (marketed as Roundup Ready ${ }^{\circledR} 2$ Technology) which confers a high level of resistance to glyphosate via expression of an insensitive EPSPS from Agrobacterium tumefaciens strain CP4 [1] [6].

Currently, glyphosate-resistant hybrids have become adopted widely in North America since their introduction. For example, over 90\% of hectares planted in Eastern Canada, the predominant Canadian corn growing region, are glyphosate-resistant hybrids [7]. In the USA, herbicide-resistant corn, glyphosate resistance the predominant weed management trait, accounted for 85\% of corn acreage by 2013 [8]. Within the glyphosate-resistant corn production system, glyphosate provides broad spectrum weed control, low cost of weed control, low crop phytotoxicity, and greater crop yields. To simplify weed management, Ontario corn growers typically rely on one or two glyphosate applications: one early postemergence (3- to 4-leaf growth stage) application, one late postemergence (7- to 8-leaf growth stage) application, or an early followed by a late postemergence application [9]-[12]. While $1800 \mathrm{~g} \cdot \mathrm{ae}^{-h^{-1}}$ of glyphosate is the maximum rate allowed in a single application [13], spray overlaps or misapplications in the field could result in corn being exposed to higher than intended doses. In addition, sometimes no-till corn producers fail to apply glyphosate as a burndown prior to corn emergence. In these situations, large perennial broadleaf weeds may be present when corn is at the 1- to 2-leaf growth stage. Corn producers would like to increase the rate of glyphosate to ensure rapid, effective control but the tolerance of corn to a high rate of glyphosate at this early growth stage is unknown. Conversely, sometimes corn producers miss the registered application window due to adverse weather conditions (e.g., frequent rain events, windy conditions, etc.) or mechanical breakdowns. Large weeds may be present in corn at the 7- to 8-leaf growth stage. Producers would like to apply a higher rate of glyphosate to ensure effective control of these large weeds, but the tolerance of corn to higher rates of glyphosate at this late application timing is unknown. Therefore, the objective of this research was to determine the tolerance of corn to early or late applications of glyphosate.

\section{Materials and Methods}

\subsection{Study Establishment}

A total of fifteen field experiments were conducted over a four-year period (2009 to 2012) at various locations in Ontario, Canada and Michigan, USA (Table 1) to determine the tolerance of corn to an early or late application of glyphosate. Experiments were designed as a randomized complete block, replicated four times. Treatments in both the early and late application experiments included glyphosate applied at 900, 1800, 3600, and $7200 \mathrm{~g} \cdot \mathrm{ae} \cdot \mathrm{ha}^{-1}$ and a weed-free control. Glyphosate doses of 3600 and $7200 \mathrm{~g} \cdot \mathrm{ae} \cdot \mathrm{ha}^{-1}$ represent a two- and fourfold increase of the maximum labeled rate, respectively; these doses were selected to simulate spray overlaps in a field. Glyphosate-resistant corn hybrids (Table 1) were seeded 4 to $5 \mathrm{~cm}$ deep at a rate of approximately 78,000 seeds $h^{-1}$ in rows spaced $75 \mathrm{~cm}$ apart into plots 2 to $3 \mathrm{~m}$ wide by 8 to $10 \mathrm{~m}$ long. Glyphosate was applied at the spike or 1- to 2-leaf corn growth stage (i.e., early application) or at the 8- or 10-leaf corn growth stage (i.e., late application experiments) using a $\mathrm{CO}_{2}$ pressurized backpack sprayer calibrated to deliver $200 \mathrm{~L} \cdot \mathrm{ha}^{-1}$ of water at $207 \mathrm{kPa}$ through Ultra-Low Drift 120-02 nozzles (Hypro, New Brighton, MN) in Ontario. In Michigan, glyphosate treatments were applied with a tractor-mounted sprayer calibrated to deliver $184 \mathrm{~L}^{\cdot \mathrm{ha}^{-1}}$ of water $^{-1}$ 
Table 1. Planting date, emergence date, and corn hybrids for fifteen field trials established from 2009 to 2012 at various locations in Ontario, Canada and Michigan, USA to examine the tolerance of corn to early and late applications of glyphosate.

\begin{tabular}{|c|c|c|c|c|}
\hline Location $^{\mathrm{a}}$ & Year & Planting date & Emergence date & Corn hybrid \\
\hline \multicolumn{5}{|c|}{ Early application trials } \\
\hline \multirow[t]{3}{*}{ Exeter, ON } & 2010 & April 21 & May 5 & DKC 46-07 \\
\hline & 2011 & May 12 & May 23 & DKC 46-07 \\
\hline & 2012 & April 19 & May 9 & DKC 44-92 \\
\hline \multirow[t]{3}{*}{ Ridgetown, ON } & 2010 & April 30 & May 9 & DKC50-45 \\
\hline & 2011 & May 12 & May24 & DKC 52-59 \\
\hline & 2012 & May 11 & May 19 & DKC 56-33 \\
\hline \multicolumn{5}{|c|}{$\underline{\text { Late application trials }}$} \\
\hline \multirow[t]{3}{*}{ Exeter, ON } & 2009 & May 6 & May 20 & Pioneer 38M58 \\
\hline & 2010 & April 21 & May 5 & DKC 46-07 \\
\hline & 2011 & May 12 & May 23 & DKC 46-07 \\
\hline Harrow, ON & 2011 & June 1 & June 6 & DKC 61-21 \\
\hline \multirow[t]{3}{*}{ Ridgetown, ON } & 2009 & May 13 & May 22 & Pioneer 35F44 \\
\hline & 2010 & April 30 & May 9 & DKC50-45 \\
\hline & 2011 & May 12 & May 24 & DKC 52-59 \\
\hline Entrican, MI & 2010 & April 28 & - & DKC 46-61 \\
\hline East Lansing, MI & 2011 & May 10 & - & DKC 46-61 \\
\hline
\end{tabular}

${ }^{\mathrm{a}}$ Exeter $\left(43.3500^{\circ} \mathrm{N}, 81.4833^{\circ} \mathrm{W}\right)$, Harrow $\left(42.0333^{\circ} \mathrm{N}, 82.9167^{\circ} \mathrm{W}\right)$, Ridgetown $\left(42.4406^{\circ} \mathrm{N}, 81.8842^{\circ} \mathrm{W}\right)$, Entrican $\left(43.3503^{\circ} \mathrm{N}, 85.1536^{\circ} \mathrm{W}\right)$, and East Lansing $\left(42.7348^{\circ} \mathrm{N}, 84.4808^{\circ} \mathrm{W}\right)$.

at $207 \mathrm{kPa}$ through Tee-Jet XR 8003 nozzles (Spraying Systems Co., Glendale Heights, IL). All plots were maintained weed-free for the entire growing season using preemergence herbicides and hand weeding as needed.

\subsection{Data Collection and Analysis}

Visible crop injury was rated 1, 2, and 4 weeks after treatment (WAT) based on a scale of $0 \%$ (no injury) to $100 \%$ (complete plant death) relative to untreated control plants grown under weed free conditions. Average cob length and cob deformity were recorded at physiological maturity using ten randomly selected ears from within each plot. Cob length was assessed by measuring fully exposed ears from end to end; whereas cob deformity was a visual approximation of the percentage of the ear that was free from exhibiting the symptoms of squashed kernels, swollen kernels, aborted kernels, and/or twisted kernel rows based on a scale of 10 (no injury) to 0 (completely deformed). Corn was harvested in October or November using a small plot combine and crop moisture and weight was recorded; final yields were converted to $15.5 \%$ seed moisture content.

Data for corn injury, cob length, cob deformity, crop moisture, and yield were analyzed using PROC MIXED (SAS Ver. 9.2, SAS Institute Inc., Cary, NC). Variances were divided into fixed (glyphosate treatment) and random effects [block; location (i.e., location-year combinations); and the glyphosate treatment $\times$ location interaction]. The significance of the fixed effect was tested using an F-test and the significance of random effects was tested using a Z-test of the variance estimate. PROC UNIVARIATE in SAS was used to test data for normality and homogeneity of variance. Data were pooled into environment groups (i.e., Environ1 and Environ2) based on a significance level of the treatment $\times$ location interaction. Means were separated using Fisher's Protected LSD at $\mathrm{P}<0.05$. Data in the late glyphosate application experiment were averaged across glyphosate doses within glyphosate timings and compared using pre-planned orthogonal contrasts in PROC MIXED in SAS. The contrasts that were evaluated included: 1) 8-leaf vs. 10-leaf growth stage, 2) untreated vs. 8-leaf growth stage, and 3) untreated vs. 10-leaf growth stage. 


\section{Results and Discussion}

\subsection{Early Application Experiments}

No visible injury was detected with applications of up to $3600 \mathrm{~g} \cdot \mathrm{ae} \cdot \mathrm{ha}^{-1}$ of glyphosate, whereas $1.4 \%$ injury was observed 4 WAT when 7200 g.ae $\cdot \mathrm{ha}^{-1}$ was applied to 1- to 2-leaf stage corn (Table 2). Yet, by harvest, the overall impact of this injury was negligible with regards to cob length, moisture content, and final yield. Corn injury symptoms included chlorotic speckling of leaf tissue, a slight decrease in growth, and slight cob deformity compared to the untreated control. High levels of glyphosate tolerance for corn carrying the NK603 event have been previously reported. For example, reference [6] found that by 2 WAT with $3360 \mathrm{~g} \cdot \mathrm{ae}^{\mathrm{h}} \mathrm{ha}^{-1}$ of gly- $^{-}$ phosate, leaf chlorosis, leaf malformation, and plant height of corn treated at the V4 growth stage were similar to an untreated control. However, reference [14] reported that while 100\% of 3-leaf stage corn survived 2 WAT with 4000 g.ae $\cdot \mathrm{ha}^{-1}$ of glyphosate, a $26 \%$ reduction in leaf fresh weight compared to the untreated control was observed. Although the relative differences in corn tolerance between the aforementioned studies and the current study appear to be notable, they may simply be the differences between lines within a breeding program and commercially available hybrids. Regardless, to the best of our knowledge, no previous study has demonstrated that corn can tolerate a four-fold increase over the maximum labeled glyphosate rate with no impact on yield, notwithstanding an observation of slight cob deformity when $7200 \mathrm{~g} \cdot \mathrm{ae}^{\mathrm{h}} \mathrm{ha}^{-1}$ was applied at the 1- to 2-leaf stage (Table 2).

\subsection{Late Application Experiments}

As expected, at all observation timings, visible injury of corn treated with 900 or $1800 \mathrm{~g} \cdot \mathrm{ae}^{\mathrm{h}} \cdot \mathrm{ha}^{-1}$ of glyphosate at the 8- or 10-leaf stage were similar to the untreated control (Table 3). However, visible injury tended to increase with glyphosate dose. In addition, injury from $7200 \mathrm{~g} \cdot \mathrm{ae} \cdot \mathrm{ha}^{-1}$ applied at the 10-leaf stage tended to increase over time with $6 \%, 11 \%$, and $12 \%$ injury observed 1,2 , and 4 WAT, respectively (Table 3 ). Corn injury symptoms included speckling of leaf tissue, chlorosis, necrosis, degradation of the leaf tissue of leaves present in the whorl at the time of application, wrapped leaves, and reduced growth compared to the untreated control. Reference [6] reported up to $10 \%$ leaf malformation of corn when a total of $5040 \mathrm{~g} \cdot \mathrm{ae}^{\mathrm{h}} \mathrm{ha}^{-1}$ was applied over sequential applications at the V4 and V8 growth stage. Yet, in the same study, two sequential applications totaling 6720 $\mathrm{g} \cdot \mathrm{ae} \cdot \mathrm{ha} \mathrm{a}^{-1}$ resulted in $3 \%$ leaf malformation that was statistically no different than the $0 \%$ reported for the untreated control.

Much like the visible injury of vegetative tissue, injury to reproductive structures and reductions in yield tended to increase with glyphosate dose, especially for corn treated at the 10-leaf stage (Table 3). Similar to the

Table 2. Tolerance of corn to an early application of glyphosate (i.e., spike and 1- to 2-leaf growth stage) at two locations (Exeter and Ridgetown) in Ontario, Canada from 2010 to $2012^{\mathrm{a}}$.

\begin{tabular}{|c|c|c|c|c|c|c|c|c|}
\hline \multirow[t]{2}{*}{ Treatment } & \multirow{2}{*}{$\begin{array}{c}\begin{array}{c}\text { Glyphosate } \\
\text { dose }\end{array} \\
\mathrm{g} \cdot \mathrm{ae} \cdot \mathrm{ha}^{-1}\end{array}$} & \multicolumn{3}{|c|}{ Visual crop injury (\%) } & \multirow{2}{*}{$\begin{array}{c}\text { Cob length } \\
\mathrm{cm}\end{array}$} & \multirow{2}{*}{$\begin{array}{c}\begin{array}{c}\text { Cob } \\
\text { deformity }\end{array} \\
0-10\end{array}$} & \multirow{2}{*}{$\begin{array}{c}\begin{array}{c}\text { Crop } \\
\text { moisture }\end{array} \\
\%\end{array}$} & \multirow{2}{*}{$\begin{array}{c}\text { Crop yield } \\
\text { T.ha }{ }^{-1}\end{array}$} \\
\hline & & $1 \mathrm{WAT}$ & $2 \mathrm{WAT}$ & 4 WAT & & & & \\
\hline Untreated & & 0a & ob & ob & $20.2 \mathrm{a}$ & $10.0 \mathrm{a}$ & $21.2 \mathrm{a}$ & $14.7 \mathrm{a}$ \\
\hline \multirow[t]{4}{*}{ Spike } & 900 & 0a & $0 \mathrm{~b}$ & $0 \mathrm{~b}$ & 20.1a & $9.9 \mathrm{a}$ & $21.0 \mathrm{a}$ & $14.6 \mathrm{a}$ \\
\hline & 1800 & 0a & $0 \mathrm{~b}$ & $0 \mathrm{~b}$ & $20.2 \mathrm{a}$ & $9.9 \mathrm{a}$ & $21.2 \mathrm{a}$ & $14.8 \mathrm{a}$ \\
\hline & 3600 & 0a & $0 \mathrm{~b}$ & $0 \mathrm{~b}$ & $20.2 \mathrm{a}$ & $9.8 \mathrm{a}$ & 21.3a & $14.6 \mathrm{a}$ \\
\hline & 7200 & $0.8 \mathrm{a}$ & $0.6 \mathrm{ab}$ & $0.9 \mathrm{ab}$ & $20.2 \mathrm{a}$ & $9.8 \mathrm{a}$ & $21.0 \mathrm{a}$ & $14.4 \mathrm{a}$ \\
\hline \multirow[t]{4}{*}{ 1- to 2-leaf } & 900 & 0a & $0 \mathrm{~b}$ & $0 \mathrm{~b}$ & $20.3 a$ & 9.9a & $21.2 \mathrm{a}$ & $14.7 \mathrm{a}$ \\
\hline & 1800 & 0a & ob & $0 \mathrm{~b}$ & $20.4 \mathrm{a}$ & $9.9 \mathrm{a}$ & $21.4 \mathrm{a}$ & $14.4 \mathrm{a}$ \\
\hline & 3600 & $0.3 \mathrm{a}$ & $0.2 b$ & $0 \mathrm{~b}$ & $20.0 \mathrm{a}$ & $9.8 \mathrm{a}$ & $21.1 \mathrm{a}$ & $14.3 \mathrm{a}$ \\
\hline & 7200 & $0.6 \mathrm{a}$ & 1a & $1.4 \mathrm{a}$ & $20.0 \mathrm{a}$ & $9.4 \mathrm{~b}$ & 21.0a & $14.3 \mathrm{a}$ \\
\hline $\mathbf{L S D}_{0.05}$ & & 1.0 & 0.9 & 0.9 & 0.5 & 0.3 & 0.5 & 0.5 \\
\hline
\end{tabular}

${ }^{\mathrm{a}}$ Abbreviation: WAT, weeks after treatment; ${ }^{\mathrm{b}}$ Means followed by the same letter within a column are not significantly different according to Fisher's Protected LSD $(\mathrm{P}<0.05)$. 
Table 3. Tolerance of corn to a late application of glyphosate (i.e., 8-leaf and 10-leaf growth stage) at various locations in Ontario, Canada and Michigan, USA from 2009 to $2011^{\text {ab }}$.

\begin{tabular}{|c|c|c|c|c|c|c|c|c|c|c|}
\hline \multirow[t]{2}{*}{ Treatment } & \multirow{2}{*}{$\begin{array}{c}\begin{array}{c}\text { Glyphosate } \\
\text { dose }\end{array} \\
\mathrm{g} \cdot \mathrm{ae} \cdot \mathrm{ha}^{-1}\end{array}$} & \multicolumn{3}{|c|}{ Visual crop injury (\%) } & \multirow{2}{*}{$\begin{array}{c}\text { Cob length } \\
\mathrm{cm}\end{array}$} & \multicolumn{2}{|c|}{ Cob deformity $(0-10)$} & \multirow{2}{*}{$\begin{array}{c}\begin{array}{c}\text { Crop } \\
\text { moisture }\end{array} \\
\%\end{array}$} & \multicolumn{2}{|c|}{ Crop yield $\left(\mathrm{T} \cdot \mathrm{ha}^{-1}\right)$} \\
\hline & & $1 \mathrm{WAT}$ & 2 WAT & 4 WAT & & ${\text { Environ } 1^{\mathrm{d}}}$ & Environ2 & & Environ1 & Environ2 \\
\hline Untreated & & $0 \mathrm{~b}$ & 0c & 0c & 19.1ab & $10.0 \mathrm{a}$ & $10.0 \mathrm{a}$ & 23.9a & $15.7 \mathrm{a}$ & $12.9 \mathrm{a}$ \\
\hline \multirow[t]{4}{*}{ 8-leaf } & 900 & $0 \mathrm{~b}$ & 0c & 0c & $19.2 \mathrm{a}$ & 9.9ab & 9.8a & $24.2 \mathrm{a}$ & $15.5 \mathrm{ab}$ & 13.1a \\
\hline & 1800 & $0 \mathrm{~b}$ & 0c & 0c & $19.2 \mathrm{a}$ & $9.7 \mathrm{abc}$ & $9.8 \mathrm{a}$ & 24.1a & $15.4 \mathrm{ab}$ & $13.0 \mathrm{a}$ \\
\hline & 3600 & $2 b$ & $1 \mathrm{c}$ & $1 \mathrm{c}$ & 19.3a & $9.4 \mathrm{bc}$ & 9.8a & $24.0 \mathrm{a}$ & $15.6 \mathrm{a}$ & $12.9 \mathrm{a}$ \\
\hline & 7200 & $6 a$ & $4 \mathrm{~b}$ & 3bc & 19.3a & $8.9 \mathrm{~d}$ & $9.4 \mathrm{~b}$ & 24.3a & $14.2 \mathrm{~cd}$ & 13.1a \\
\hline \multirow[t]{4}{*}{ 10-leaf } & 900 & $0 \mathrm{~b}$ & 0c & 0c & 19.1ab & 9.8ab & 9.8a & $24.1 \mathrm{a}$ & $15.5 \mathrm{ab}$ & $12.7 \mathrm{a}$ \\
\hline & 1800 & $0 \mathrm{~b}$ & 1c & $2 b c$ & $19.4 a$ & $9.3 \mathrm{~cd}$ & 9.9a & 24.1a & $14.8 \mathrm{bc}$ & $13.2 \mathrm{a}$ \\
\hline & 3600 & $2 b$ & $4 \mathrm{~b}$ & $5 b$ & 19.1ab & $8.2 \mathrm{e}$ & $9.2 \mathrm{~b}$ & 24.3a & $14.2 \mathrm{~cd}$ & $12.9 \mathrm{a}$ \\
\hline & 7200 & $6 a$ & $11 \mathrm{a}$ & $12 a$ & $18.8 \mathrm{~b}$ & $7.4 \mathrm{f}$ & $8.7 \mathrm{c}$ & 24.3a & $13.4 \mathrm{~d}$ & $12.7 \mathrm{a}$ \\
\hline \multicolumn{11}{|l|}{ Contrasts $^{\mathrm{e}}$} \\
\hline $\begin{array}{l}\text { 8-leaf vs. } \\
\text { 10-leaf }\end{array}$ & & $\begin{array}{c}\text { NS } \\
\text { (2 vs. 2) }\end{array}$ & $\begin{array}{c}* \\
(1 \text { vs. } 4)\end{array}$ & $\begin{array}{c}* \\
(1 \text { vs. } 5)\end{array}$ & $\begin{array}{c}\text { NS } \\
\text { (19.3 vs. } \\
19.1)\end{array}$ & $\begin{array}{c}* \\
(9.5 \text { vs. } 8.7)\end{array}$ & $\begin{array}{c}* \\
(9.7 \text { vs. } 9.4)\end{array}$ & $\begin{array}{c}\text { NS } \\
(24.2 \text { vs. } \\
24.2)\end{array}$ & $\begin{array}{c}* \\
(15.2 \text { vs. } \\
14.5)\end{array}$ & $\begin{array}{c}\text { NS } \\
\text { (13.0 vs. } \\
12.9)\end{array}$ \\
\hline $\begin{array}{l}\text { Untreated vs. } \\
\text { 8-leaf }\end{array}$ & & $\begin{array}{c}* \\
(0 \text { vs. } 2)\end{array}$ & $\begin{array}{c}\text { NS } \\
(0 \text { vs. } 1)\end{array}$ & $\begin{array}{c}\text { NS } \\
(0 \text { vs. } 1)\end{array}$ & $\begin{array}{c}\text { NS } \\
\text { (19.1 vs. } \\
19.3)\end{array}$ & $\begin{array}{c}* \\
(10.0 \text { vs. } \\
9.5)\end{array}$ & $\begin{array}{c}* \\
(10.0 \text { vs. 9.7) }\end{array}$ & $\begin{array}{c}\text { NS } \\
\text { (23.9 vs. } \\
24.2)\end{array}$ & $\begin{array}{c}\text { NS } \\
(15.7 \text { vs. } \\
15.2)\end{array}$ & $\begin{array}{c}\text { NS } \\
(12.9 \text { vs. } \\
13.0)\end{array}$ \\
\hline $\begin{array}{l}\text { Untreated vs. } \\
\text { 10-leaf }\end{array}$ & & $\begin{array}{c}* \\
(0 \text { vs. } 2)\end{array}$ & $\begin{array}{c}* \\
(0 \text { vs. } 4)\end{array}$ & $\begin{array}{c}* \\
(0 \text { vs. } 5)\end{array}$ & $\begin{array}{c}\text { NS } \\
\text { (19.1 vs. } \\
19.1)\end{array}$ & $\begin{array}{c}* \\
(10.0 \text { vs. } \\
8.7)\end{array}$ & $\begin{array}{c}* \\
(10.0 \text { vs. } 9.4)\end{array}$ & $\begin{array}{c}\text { NS } \\
(23.9 \text { vs. } \\
24.2)\end{array}$ & $\begin{array}{c}* \\
(15.7 \text { vs. } \\
14.5)\end{array}$ & $\begin{array}{c}\text { NS } \\
(12.9 \text { vs. } \\
12.9)\end{array}$ \\
\hline
\end{tabular}

${ }^{\mathrm{a}}$ Abbreviation: WAT, weeks after treatment; ${ }^{\mathrm{b}}$ Data are pooled across locations unless otherwise stated; ${ }^{\mathrm{c}}$ Means followed by the same letter within a column are not significantly different according to Fisher's Protected LSD $(\mathrm{P}<0.05)$; ${ }^{\mathrm{d}}$ Environ1 = Exeter 2010, Harrow 2011, Entrican 2010, Ridgetown 2009, and Ridgetown 2010; Environ2 = Exeter 2009, Exeter 2011, East Lansing 2011, and Ridgetown 2011; ${ }^{\mathrm{e} N S}$ = Not significantly different; * $=$ Significant difference at $\mathrm{P}<0.05$ according to an orthogonal contrast.

early application experiments (Table 2), cob length was largely unaffected by glyphosate dose or timing, according to preplanned orthogonal contrasts (Table 3). Conversely, cob deformity increased with glyphosate dose and was the most severe for corn treated at the 10-leaf stage (Table 3). For example, corn treated with 7200 $\mathrm{g} \cdot \mathrm{ae} \mathrm{ha}^{-1}$ displayed kernels that were squashed, swollen, or aborted and kernel rows that were twisted (Figure 1). Although cob deformity was detected in both Environ1 and Environ2, only the cob deformity observed in Environ1 negatively impacted yield. In Environ1, corn treated with $7200 \mathrm{~g} \cdot \mathrm{ae} \cdot \mathrm{ha}^{-1}$ at the 8- and 10-leaf stage had a 9.5\% and $14.6 \%$ reduction in yield, respectively (Table 3). However, in Environ2, corn yield was not impacted by glyphosate dose or timing.

In the literature, reference [7] reported no injury or subsequent yield loss when corn was treated at the 10-leaf stage with $900 \mathrm{~g} \cdot \mathrm{ae} \cdot \mathrm{ha}^{-1}$ of glyphosate. However, in Ontario, a single application of glyphosate at or after the 8-leaf stage risks yield loss due to early-season competition with weeds [15] and is not recommended [9]. Furthermore, physiological stresses in a corn plant at early developmental stages may affect kernel number [16] since the reproductive organs are initiated around the 5- to 6-leaf stage, with the ear actively growing by the 8to 10-leaf stage [17]. In the current study, in addition to being applied later than recommended, greater doses of glyphosate than recommended [9] [13] were used. Glyphosate has been shown to accumulate in meristematic

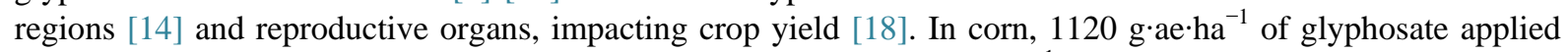
after V6 or sequential applications of glyphosate totaling $2240 \mathrm{~g} \cdot \mathrm{ae}^{\mathrm{h}} \mathrm{a}^{-1}$ reduced pollen viability, with glyphosate accumulation in the tassel the speculative cause [19]. In this same study, glyphosate was also thought to have accumulated in the ear; yet, kernel-set was not affected. Unfortunately, with regards to the current study, a precise, physiological explanation for the observations of cob deformity and yield loss was not one of the original objectives and was not examined. 


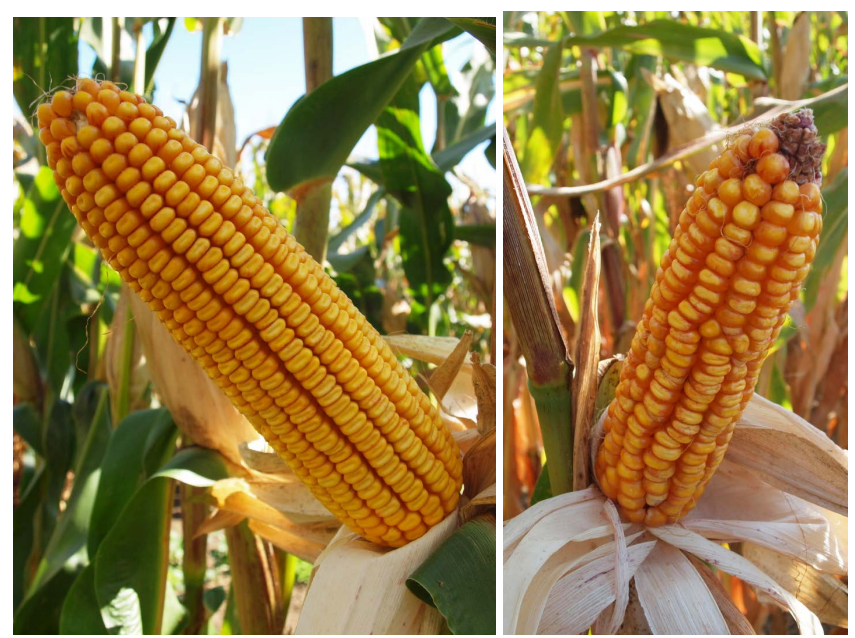

Figure 1. Corn at physiological maturity after treatment with 900 $\mathrm{g} \cdot \mathrm{ae}^{\mathrm{h}} \mathrm{ha}^{-1}$ of glyphosate at the 8-leaf growth stage (left-facing ear) and $7200 \mathrm{~g} \cdot \mathrm{ae} \cdot \mathrm{ha}^{-1}$ at the 10 -leaf growth stage (right-facing ear).

\section{Conclusion}

This research demonstrated that commercially available corn hybrids containing the NK603 transgenic event can exhibit tolerance to glyphosate at doses far greater than what has been previously published [6] [14] or could reasonably be expected during spray overlaps in a field. Furthermore, corn can tolerate an application of up to $7200 \mathrm{~g} \cdot \mathrm{ae} \cdot \mathrm{ha}^{-1}$ of glyphosate from the spike to the 8-leaf stage with a minimal effect on yield. However, by the 8-leaf stage, the ear is an active mertistematic area [17] and glyphosate will likely accumulate [19]. The cob deformities that reduced yield in this study could have been caused by a deleterious accumulation of glyphosate. Therefore, for corn to be able tolerate a high dose of glyphosate late in the growing season without affecting yield, it may be advantageous for plants to have the ability to metabolically detoxify glyphosate. However, corn containing this type of transgenic event is currently not commercially available [1] [2].

\section{Acknowledgements}

The authors acknowledge Lynette Brown, Christy Shropshire, Todd Cowan, Elaine Lepp, and Andy Chomas for their technical assistance in these studies.

\section{References}

[1] Green, J.M. (2009) Evolution of Glyphosate-Resistant Crop Technology. Weed Science, 57, 108-117. http://dx.doi.org/10.1614/WS-08-030.1

[2] Pline-Srnić, W. (2006) Physiological Mechanisms of Glyphosate Resistance. Weed Technology, 20, 290-300. http://dx.doi.org/10.1614/WT-04-131R.1

[3] Pollegioni, L., Schonbrunn, E. and Siehl, D. (2011) Molecular Basis of Glyphosate Resistance-Different Approaches through Protein Engineering. FEBS Journal, 278, 2753-2755. http://dx.doi.org/10.1111/j.1742-4658.2011.08214.X

[4] Vande Berg, B.J., Hammer, P.E., Chun, B.L., Schouten, L.C., Carr, B., Guo, R., Peters, C., Hinson, T.K., Beilinson, V., Shekita, A., Deter, R., Chen, Z., Samoylov, V., Bryant, C.T., Stauffer, M.E., Eberle, T., Moellenbeck, D.J., Carozzi, N.B., Koziel, M.G. and Duck, N.B. (2008) Characterization and Plant Expression of a Glyphosate-Tolerant Enolpyruvylshikimate Phosphate Synthase. Pest Management Science, 64, 340-345. http://dx.doi.org/10.1002/ps.1507

[5] Castle, L.A., Siehl, D.L., Gorton, R., Patten, P.A., Chen, Y.H., Bertain, S., Cho, H., Duck, N., Wong, J., Liu, D. and Lassner, M.W. (2004) Discovery and Directed Evolution of a Glyphosate Tolerance Gene. Science, 304, 1151-1154. http://dx.doi.org/10.1126/science.1096770

[6] Heck, G.R., Armstrong, C.L., Astwood, J.D., Behr, C.F., Bookout, J.T., Brown, S.M., Cavato, T.A., DeBoer, D.L., Deng, M.Y., George, C.Hillyard, J.R., Hironaka, C.M., Howe, A.R., Jakse, E.H., Ledesma, B.E., Lee, T.C., Lirette, R.P., Mangano, M.L., Mutz, J.N., Qi, Y., Rodriguez, R.E., Sidhu, S.R., Silvanovich, A., Stoecker, M.A., Yingling, R.A. and You, J. (2005) Development and Characterization of a CP4 EPSPS-Based, Glyphosate-Tolerant Corn Event. Crop 
Science, 45, 329-339. http://dx.doi.org/10.2135/cropsci2005.0329

[7] Soltani, N., Nurse, R.E., Page, E.P., Everman, W.J., Sprague, C.L. and Sikkema, P.H. (2013) Influence of Late Emerging Weeds in Glyphosate-Resistant Corn. Agricultural Sciences, 4, 275-281. http://dx.doi.org/10.4236/as.2013.46039

[8] US Department of Agriculture-Economic Research Service (2014) Adoption of Genetically Engineered Crops in the U.S. http://www.ers.usda.gov/data-products/adoption-of-genetically-engineered-crops-in-the-us/recent-trends-in-ge-adoptio $\underline{\mathrm{n}}$

[9] Ontario Ministry of Agriculture, Food and Rural Affairs (2012) Guide to Weed Control. Toronto, Publication 75, 400 p.

[10] Nurse, R.E., Swanton, C.J., Tardif, F. and Sikkema, P.H. (2006) Weed Control and Yield Are Improved When Glyphosate Is Preceded by a Residual Herbicide in Glyphosate-Tolerant Maize (Zea mays). Crop Protection, 25, 11741179. http://dx.doi.org/10.1016/j.cropro.2006.02.015

[11] Soltani, N., Stewart, C.L., Nurse, R.E., Van Eerd, L.L., Vyn, R.J. and Sikkema, P.H. (2012) Weed Control, Environmental Impact and Profitability of Weed Management Strategies in Glyphosate-Resistant Corn. American Journal of Plant Science, 3, 1594-1607. http://dx.doi.org/10.4236/ajps.2012.311193

[12] Stewart, C.L., Soltani, N., Nurse, R.E., Hamill, A.S. and Sikkema, P.H. (2012) Precipitation Influences Pre- and PostEmergence Herbicide Efficacy in Corn. American Journal of Plant Science, 3, 1193-1204. http://dx.doi.org/10.4236/ajps.2012.39145

[13] Anonymous (2011) Roundup WeatherMAX ${ }^{\circledR}$ Herbicide Product Label. Monsanto Canada Inc., Winnipeg. http://roundup.ca/_uploads/documents/ru_wmax_label_english.pdf

[14] Hetherington, P.R., Reynolds, T.L., Marshall, G. and Kirkwood, R.C. (1999) The Absorption, Translocation and Distribution of the Herbicide Glyphosate in Maize Expressing the CP-4 Transgene. Journal of Experimental Botany, 50, 1567-1576. http://dx.doi.org/10.1093/jxb/50.339.1567

[15] Page, E.R., Cerrudo, D., Westra, P., Loux, M., Smith, K., Foresman, C., Wright, H. and Swanton, C.J. (2012) Why Early Season Weed Control Is Important in Maize. Weed Science, 60, 423-430. http://dx.doi.org/10.1614/WS-D-11-00183.1

[16] Maddonni, G.A. and Otegui, M.E. (2004) Intra-Specific Competition in Maize: Early Establishment of Hierarchies among Plants Affects Final Kernel Set. Field Crops Research, 85, 1-13. http://dx.doi.org/10.1016/S0378-4290(03)00104-7

[17] Lejeune, P. and Bernier, G. (1996) Effect of Environment on the Early Steps of Ear Initiation in Maize (Zea mays L.). Plant, Cell \& Environment, 19, 217-224. http://dx.doi.org/10.1111/j.1365-3040.1996.tb00243.x

[18] Pline, W.A., Wilcut, J.W., Duke, S.O., Edmisten, K.L. and Wells, R. (2002) Tolerance and Accumulation of Shikimic Acid in Response to Glyphosate Applications in Glyphosate-Resistant and Nonglyphosate-Resistant Cotton (Gossypiumhirsutum L.). Journal of Agricultural and Food Chemistry, 50, 506-512. http://dx.doi.org/10.1021/jf0110699

[19] Thomas, W.E., Pline-Srnić, W.A., Thomas, J.F., Edmisten, K.L., Wells, R. and Wilcut, J.W. (2009) Glyphosate Negatively Affects Pollen Viability But Not Pollination and Seed Set in Glyphosate-Resistant Corn. Weed Science, 52, 725 734. http://dx.doi.org/10.1614/WS-03-134R

\section{Abbreviations}

EPSPS, 5-enolpyruvylshikimate-3-phosphate synthase WAT, weeks after treatment 
Scientific Research Publishing (SCIRP) is one of the largest Open Access journal publishers. It is currently publishing more than 200 open access, online, peer-reviewed journals covering a wide range of academic disciplines. SCIRP serves the worldwide academic communities and contributes to the progress and application of science with its publication.

Other selected journals from SCIRP are listed as below. Submit your manuscript to us via either submit@scirp.org or Online Submission Portal.
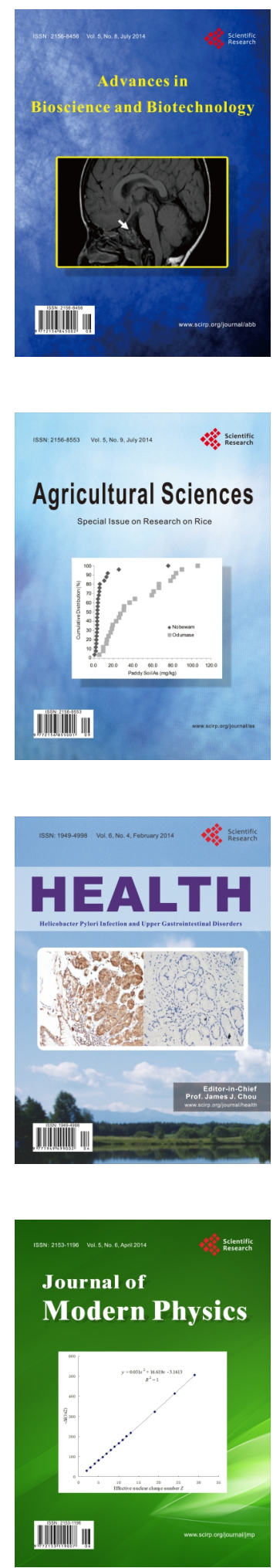
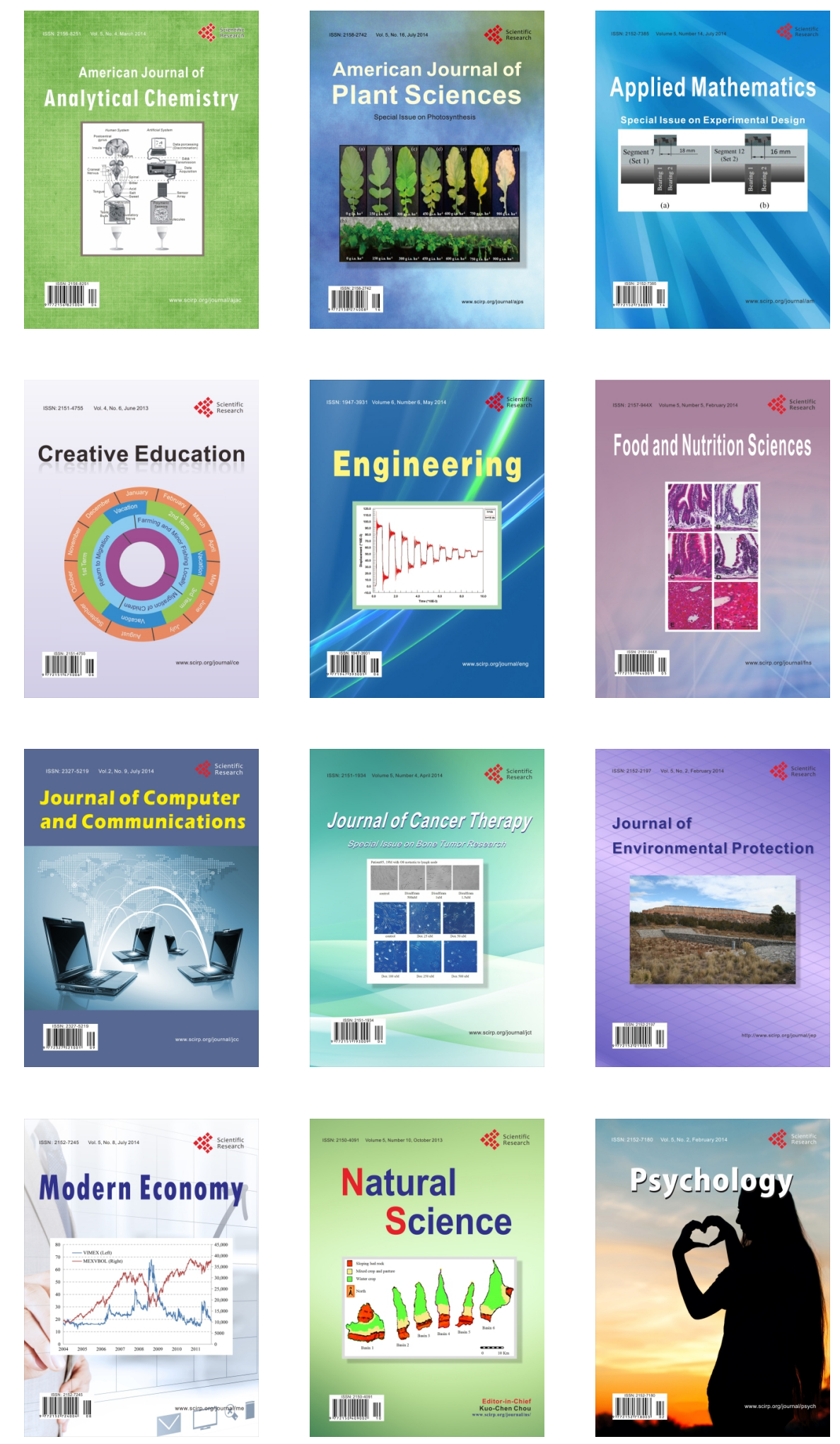